\title{
Introduction to Law, Solidarity and the Limits of Social Europe
}

\section{Ann-Christine Hartzén, Andrea Iossa and Eleni Karageorgiou}

\section{THE UNION IN A CONSTANT STATE OF 'CRISIS': CAUSES AND IMPLICATIONS}

Since the Maastricht Treaty of 1992, we have witnessed a barrage of political interventions as well as scholarly debates and analyses aimed at identifying, exploring and addressing the causes and effects of the multiple crises generated by EU law and policy. These debates concern problems central to the very constitution (in the legal as well as the sociological sense of the word) of the EU. In recent years, scholarly investigations of those aspects have steadily grown, addressing issues that range from the EU's deteriorating representation, its legitimacy and democratic deficit ${ }^{1}$ to its failure to promote an integration between states and citizens that goes beyond the mere economic aspects. ${ }^{2}$ These factors have then produced more specific situations of crisis, such as the crisis of solidarity in the Eurozone, ${ }^{3}$ the so-called migration

\footnotetext{
1 Simona Piattoni, The European Union: Democratic Principles and Institutional Architectures in Times of Crisis (OUP 2015); Andrea Biondi, Egle Dagilyte and Esin Kucuk (eds), Solidarity in EU Law: Legal Principle in the Making (Edward Elgar Publishing 2018).

2 Francesca Bignami (ed), EU Law in Populist Times: Crises and Prospects (CUP 2020); Christian Lahusen (ed), Citizens' Solidarity in Europe: Civic Engagement and Public Discourse in Times of Crises (Edward Elgar Publishing 2020).

3 Silvana Sciarra, Solidarity and Conflict: European Social Law in Crisis (CUP 2018); Eva Nanopoulos and Fotis Vergis (eds), The Crisis behind the Eurocrisis: The Eurocrisis as a Multidimensional Systemic Crisis of the EU (CUP 2019); Tomasz Morozowski and Jacek Kubera (eds), A 'Social Turn' in the European Union? New Trends and Ideas about Social Convergence in Europe (Routledge 2020).
} 
crisis $^{4}$ - also regarded as a 'crisis of solidarity' ${ }^{5}$ - and Brexit. ${ }^{6}$ It has been even argued that political crises have become the normal state of affairs in the EU. ${ }^{7}$ Notwithstanding the intensive political debate and the academic research and theorising, many of the factors and mechanisms which generated the array of EU crises continue to persist, posing fundamental challenges to the endurance of the EU integration as a constitutional project. These factors are closely related to, inter alia, labour mobility, asylum and external border management and austerity measures, generating an unequal distribution of power and resources between the social and political actors (national governments, NGOs, trade unions, EU institutions and the EU itself as a polity) involved in the development and maintenance of the EU project and of its Social Model. ${ }^{8}$ The ongoing COVID-19 pandemic has been the latest example of the Union's institutional limitations, in terms of the way in which inequality manifests itself in a situation of a global and regional health emergency.

Starting from these premises, Law, Solidarity and the Limits of Social Europe offers a scholarly account of the socio-legal mechanisms that drive EU constitutional tensions, leading to crisis-like situations, and of the role of solidarity-based principles and values in redirecting EU law and policy towards a democratic Social Europe. It does this by addressing the existing constitutional limits of Social Europe in two wide but well-defined and interwoven areas: social rights and labour relations, on the one hand; mobility within and to the EU, on the other. In particular, the contributions in this volume touch upon questions relating to posting of workers and social dumping, the right to collective bargaining, economic governance, political rights and free movement for EU citizens, asylum and migration policy and Brexit. Although these substantive issues might appear to be only loosely connected, they nev-

4 See among others, Vladislava Stoyanova and Eleni Karageorgiou (eds), The New Asylum and Transit Countries in Europe during and in the Aftermath of the 2015/2016 Crisis (Brill 2018).

5 See Marianne Takle, 'Is the Migration Crisis a Solidarity Crisis?' in Andreas Grimmel (ed), The Crisis of the European Union. Challenges, Analyses, Solutions (Routledge 2018).

6 See Federico Fabbrini (ed), The Law \& Politics of Brexit (OUP 2017), in particular the contributions included in Part 3 on 'Brexit and Constitutional Change in European Perspective'; Paul James Cardwell, 'The End of Exceptionalism and a Strengthening of Coherence? Law and Legal Integration in the EU Post-Brexit' (2019) 57(6) Journal of Common Market Studies 1407.

7 Sarah Wolff and Stella Ladi, 'European Union Responses to the Covid-19 Pandemic: Adaptability in Times of Permanent Emergency' (2020) 42(8) Journal of European Integration 1025.

8 Helle Krunke, Hanne Petersen and Ian Manners (eds), Transnational Solidarity: Concept, Challenges and Opportunities (CUP 2020). 
ertheless represent different scales of the EU's constitutional limits. Through a critical assessment of EU integration and its inherent tensions as reflected in EU law and Member State practices, the volume aims at complementing traditional concepts and methodologies on the EU constitutional debate with newly emerged elements stemming from the analysis of socio-political dynamics embedded in the EU project. By paying attention to empirically discernible effects of EU policy in the field of social rights, labour relations and mobility, this book contributes to the debate on the multiple legal and policy challenges for Social Europe. In particular, it investigates the mechanisms through which 'crises' are produced and take form, and how, ultimately, they challenge solidarity as a grounding principle in the EU legal order. This sheds new light on the causes of those challenges and on the institutional and constitutional limitations that the EU faces in managing them. Ultimately, the volume suggests new paths to enhance the role of EU constitutional principles and values for a future Social Europe grounded in solidarity.

\section{RECONCILING THE SOCIAL AND THE ECONOMIC: A FEASIBLE TASK?}

The volume is divided into two main parts. The contributions offer a cross-disciplinary and policy-oriented analysis of the topics by undertaking legal, political science, sociological and philosophical perspectives. Starting from this diversity, they all converge towards illustrating what a more principled approach to social rights in EU law would look like. Their ultimate common ground lies in the exploration of pathways for grounding Social Europe in the concept and practice of solidarity.

\subsection{Social Rights and Labour Relations}

The main issue investigated in Part I concerns the driving force of never-ending tension and discussion in the context of EU integration: the conflict between the economic and the social dimensions of the EU. The contributions focus on the limits to the full development of Social Europe deriving from social dumping, the regulation of labour mobility, economic governance and social partners' involvement in rule-making processes. In particular, the authors highlight how these distinct yet complementary dynamics, fostered by the EU's constitutional structure and embedded into its regulatory framework, have contributed in de-legitimising the process of EU integration by, for instance, fuelling Euro-scepticism. By interrogating the challenges deriving from the mismatch between the uniform application of economic-oriented law and policy and the diversity of labour law and industrial relations regimes in the EU, the contributions to this part of the volume raise questions about, 
among others, social integration, solidarity, fair competition, democratic participation and representation, human dignity and equal treatment.

Novitz kicks off with an analysis of the European Pillar of Social Rights from a sustainability perspective. She examines the EU's claims to promote social sustainability both within the internal market and in its external relations. After considering the potential meaning of social sustainability and reflecting on this issue in Agenda 2030 and the Sustainable Development Goals, her chapter probes the meaning of social dumping in this context by addressing the relevance of substantive labour standards and procedural rights (including those relating to workers' voice), alongside the constituency of those who can claim them.

Subsequently, Lo Faro follows up on the question of social dumping within the context of transnational mobility of workers. In his contribution, this question is tackled by discussing the fraudulent and abusive practices of posting of workers put in place by 'letterbox companies'. He conducts a thorough and analytical investigation of the loopholes offered by EU free movement and internal market law fostering practices of artificial posting, and of the possible available remedies. Ultimately, Lo Faro's analysis unveils how those tensions and limits lie inherently at the core of the labour and service mobility in the EU internal market, raising conflicts of solidarity across labour markets and among workers.

Dorssemont's chapter zooms in on the role of the CJEU and the implications of judicial reasoning for democracy, subsidiarity and social policy in the EU. The chapter discusses Case T-310/18 European Federation of Public Service Unions (EPSU) and Jan Willem Goudriaan v European Commission by providing a critical assessment both of the legal argumentation and of its consequences for the European Social Dialogue. Dorssemont looks at the latter as a process providing the EU with a means for ensuring democratic participation and a horizontal dimension of subsidiarity in social policy. In doing so, he questions the position of the Commission and the ruling of the General Court in relation to the Agreement on information and consultation for employees in central government administrations both from the perspective of equality for workers in this sector and from an overarching perspective on democratic aspects of Social Europe.

Along a similar path, Pecinovsky discusses the right to collective bargaining as exercised at the national level within the intersection between EU economic governance and fundamental social rights. By using the example of Spain, he shows how EU soft law measures implemented through the instrument of country-specific recommendations have resulted in national actions that encroach upon the fundamental right of the social partners to collective bargaining. The discussion also illustrates the evolution that has characterised the EU economic governance instruments with the aim of reconciling their aims 
with the respect of fundamental social rights. Starting with an analysis of those instruments under the Junker Commission and moving towards the view of the Van der Leyden Cabinet, the chapter ends with a up-to-date account in the context of the current COVID-19 crisis. Ultimately, Pecinovsky hints at the possible definitive shift away from austerity as a way to promote economic recovery in the EU.

In the same vein, Johansson looks at the Swedish model of labour market regulation in the prism of the European Social Model. Her chapter discusses the tensions between the supranational and national levels as illustrated by the position of the Swedish social partners, the legislator and the parliament in the negotiations and the adoption of Directive 2019/1152 on transparent and predictable working conditions in the European Union. By grounding the analysis in the interests of the Swedish social partners to safeguard the national model against possible interference from EU law and policies, Johansson focuses not on the tension between 'the economic' and 'the social' within the EU, but rather on the tension between 'the social' at EU level and 'the social' at national level. In this sense, the analysis offers an interesting perspective on the limits of harmonisation in the social policy field. Ultimately, an argument is made that treaty changes are needed in order to strengthen the legislator at both national and EU level, and to better ensure the Member States' room for manoeuvre to safeguard their welfare models.

\subsection{Mobility, Brexit and the Question of Solidarity}

As Part I demonstrates, the EU faces structural challenges in relation to social integration, fair competition, human dignity, equal treatment and social rights. Part II explores these challenges further in relation to mobility and migration against the background of Brexit. These challenges are discussed as concrete outcomes of the EU's failure to deliver on expectations for law and policy based on solidarity, mutual trust and fundamental rights. The four contributions that compose this part discuss constitutional tensions between internal market considerations on the one hand, and fundamental rights and political participation on the other. The aim is to offer a balanced account of the ways in which a principled approach, in line with established regional and international standards, could inform the future transformation of EU policies in a way that is fair to EU citizens and non-citizens alike.

In his contribution, Kouroutakis points at the fact that, in the EU, strong economic rights do not necessarily go hand in hand with strong political rights. This asymmetry has been highlighted by the June 2016 referendum on Brexit. Despite the inevitable impact on EU citizens who live and work in the UK and on British citizens who live and work in another EU country, most of those belonging to both groups, while exercising their free movement rights, did 
not have the right to participate in the referendum. According to Kouroutakis, this asymmetry between economic and political rights marks a constitutional 'cacophony' in EU citizenship. By examining the free movement of workers from a political perspective, the chapter argues that EU citizens who exercise their free movement rights on the one hand have limited rights to participate in the political life of the host country, and on the other might lose their political rights in their countries of origin. Ultimately, this stresses a deficiency in the application of the principle of solidarity across the EU.

Along the same lines, Bengoetxea explores how solidarity as a value has been put to the test with the 2015 refugee crisis. The chapter discusses solidarity as a constitutional value in the EU and the way in which it has informed policies that effectively establish a fair sharing of responsibility between EU Member States in practice. He argues that the internal cleavage between EU Member States of the North, South, East and West has played a significant role in how solidarity has been perceived and applied during the crisis. The chapter's main argument lies in the contrast between the value of solidarity as proclaimed in the Treaties and the actual practice of EU policy, whereby the security constitution is placed above the solidarity constitution. In this respect the chapter concludes with a call to revive the spirit of solidarity in the EU through actual practice and policy, reclaiming its constitutional status.

In the following chapter, Vergis uses the example of Brexit to query the extent to which 'substantive constitutionalisation' may help 'win back minds and hearts' of those who have been disenchanted by the recent EU law and policies. According to Vergis, the multiple 'crises' seen in succession during the past decade, culminating in the Brexit saga, have challenged the traditional narrative of perpetual 'further integration', and have revealed systemic flaws in the EU's structure and normative basis. His chapter examines what embracing a more consistent interpretation and application of the EU constitutional framework would entail and how its normative foundations could help reverse this perception. In light of a process of 'substantive constitutionalisation', namely an interpretative approach that would require a consistent and principled judicial review of EU law and policies, Vergis argues that the social values that inform the EU constitutional framework could be used as grounds for readdressing the conduct of all EU institutions and for bridging some of the disconnect between the EU and the popular - sceptical - public perception of its nature and role.

Embracing the same forward-looking standpoint, the final chapter, by Garben, offers insights as to what a dignity- and reciprocity-based solidarity, as a normative framework, could entail for the EU's constitutional settlement. Garben delves into the notions of solidarity, dignity, competition and cooperation, and their meaning for the project of European integration. The chapter argues that, in order to ensure its stability and success as a federal system, the 
EU needs to better institutionalise a mutually reinforcing two-step solidarity structure: it needs to ensure that (1) everyone participates in the common project (largely defined) without expecting a guaranteed net benefit in the immediate term, and (2) that there are sufficiently robust redistributive mechanisms in place so that individuals, groups and Member States that (structurally) lose in the common system are duly compensated.

\section{THE COVID-19 OUTBREAK AND ITS IMPACT ON SOCIAL EUROPE}

While examining long-lasting EU constitutional tensions and limits in light of newly emerged events, the contributions also reveal their incisiveness in relation to the current health crisis faced by the EU, namely the COVID-19 pandemic. It is beyond any doubt that the pandemic, and the measures adopted to address it, had - and still have - a profound impact on the areas of EU law and policy that the contributions in this volume discuss. Although we contend that it is rather early to fully comprehend the impact of the pandemic on EU law and social policy, and hence a detailed account of this goes beyond the scope of this volume, there are a few points that need to be raised in relation to the EU's constitutional design as discussed here. In this section, we highlight the difficulties of the EU to act as a Union in the face of the COVID-19 pandemic, which largely affects social policy and fundamental rights and the configuration of a Social Europe. These preliminary reflections highlight two aspects: first, in the absence of a coherent centralised approach in dealing with 'crises', Member States have turned to unilateral or bilateral actions in order to address challenges on the ground; second, the measures to contain the virus and to foster economic recovery seem to widen the gap between solidarity as a political rhetoric and its reality.

\subsection{Economic Recovery Measures at EU Level}

When the COVID-19 pandemic struck the EU, the consequences of the financial and sovereign debt crisis were still fresh in the minds of the Union's main policy actors. ${ }^{9}$ It was hardly possible to neglect the consequences of austerity as a response to the financial crisis ${ }^{10}$ and the ensuing demands for a more

$9 \quad$ Stella Ladi and Dimitris Tsarouhas, 'EU Economic Governance and Covid-19: Policy Learning and Windows of Opportunity' (2020) 42(8) Journal of European Integration 1041.

10 For useful discussions on the response of EU to the financial crisis in relation to social rights see Niklas Bruun, Klaus Lörcher and Isabelle Schömann (eds), The 
social Europe. ${ }^{11}$ This, it has been argued, would have possibly paved the way for quicker action and decisions on an EU economic policy concerned with a redistributive function. ${ }^{12}$ While such a conclusion might be true in relation to the Recovery and Resilience Facility (RRF) ${ }^{13}$ as part of the Commission's Next Generation EU (NGEU) proposal, ${ }^{14}$ a discussion of the role of solidarity in reaching the decision to adopt this instrument is salient. The developments leading up to the adoption of the RRF serve well to illustrate important points for the purposes of this volume. The reason for this is that the RRF as such represents a novelty in EU economic governance ${ }^{15}$ and the negotiations undertaken for its adoption highlight the need for a continuous discussion on the tensions around the practices of solidarity in the context of economic policy.

Although the pandemic affected all Member States, leading to severe strain on health-care systems, rising unemployment and drops in GDP, its consequences were asymmetrical. Some of the southern Member States, which had barely recovered from the financial crisis, have been hit harder, facing increasing debt levels that severely risk their economic and political stability. ${ }^{16}$ This group of Member States called for new forms of assistance based on grants from the EU. The initial response from northern Member States was, instead, to insist on loans with conditionality requirements. However, this changed when the German government altered its opinion. The imminent risk of economic downfall spreading from the south to the north due to interdependencies between export markets, pressure from important actors within German industry and possibilities for regained strength in the partnership with France led the Merkel cabinet to shift stance. ${ }^{17}$ This enabled Germany and France to agree upon a proposal for grants to be distributed to Member States in need, paving the way for the Commission to propose an instrument

Economic and Financial Crisis and Collective Labour Law in Europe (Hart Publishing 2014).

11 Wolff and Ladi (n 7).

12 Ladi and Tsarouhas (n 9).

13 Adopted through Council Regulation (EU) 2020/2094 of 14 December 2020 establishing a European Union Recovery Instrument to support the recovery in the aftermath of the COVID-19 crisis [2020] OJ L4331/23.

14 European Commission, 'Communication from the Commission to the European Parliament, the European Council, the Council, the European Economic and Social Committee and the Committee of the Regions - Europe's Moment: Repair and Prepare for the Next Generation' COM(2020) 456 final.

15 Antoine Camous and Grégory Claeys, 'The Evolution of European Economic Institutions during the COVID-19 Crisis’ (2020) 6(2) European Policy Analysis 328.

16 Ladi and Tsarouhas (n 9).

17 Philipp Genschel and Markus Jachtenfuchs, 'Postfunctionalism Reversed: Solidarity and Rebordering during the COVID-19 Pandemic' (2021) 28(3) Journal of European Public Policy 350. 
that would combine grants and loans. Even though this proposal was met with resistance from Austria, Denmark, the Netherlands and Sweden - the 'frugal four' - negotiations carried out in the framework of the EU budget made room for compromise. To get them on board, the 'frugal four' were granted rebates on their contributions to the EU budget and cuts in funding for certain policy areas in accordance with their requests. In these negotiations Germany also managed to retain a significant rebate on its contribution to the EU budget, while a conditionality clause concerning respect for the rule of law was changed in order to ensure acceptance from Poland and Hungary. ${ }^{18}$ By combining the negotiations on the NGEU and RFF with the negotiations on the EU long-term budget, it was thus possible to assure Member States that they would get something in return for the concessions they made.

The construction of the RRF assures an allocation of grants proportionate to the magnitude of the pandemic's effects. Several of those Member States who have been hit harder are also those with more severe structural socio-economic problems. Considering that the financing of the RRF is secured by loans taken up by the EU to be paid back by contributions to the EU budget, this instrument will involve economic transfers based on a redistribution of financial resources from the wealthier Member States to the less so. ${ }^{19}$ Even though such a mechanism would suggest a process informed by practices of solidarity, ${ }^{20}$ the negotiations that led to its adoption show that it may not have been approved unless its initial opponents had been given something in return. Both the change in the German government's position and the compromises that convinced the 'frugal four' suggest that solidarity in the EU has a particular meaning that needs to be unravelled. ${ }^{21}$ In future assessments and evaluations of the RRF and other instruments intended to facilitate recovery from the pandemic, the question of solidarity - and how it is implemented - remains of high importance, in particular as regards the interplay between EU economic policy and national policies in the context of Social Europe.

\subsection{Cross-Country (Im)mobility for EU Citizens}

Another area of EU law and policy drastically affected by the measures adopted to reduce the spread of the virus is cross-country mobility for EU citizens. While border controls and travel restrictions have been introduced across the world, these measures have a specific impact in the space of the EU, where

8 Ladi and Tsarouhas (n 9).

Camous and Claeys (n 15).

Genschel and Jachtenfuchs (n 17).

${ }^{21}$ See also Sacha Garben, ch 9 in this volume. 
freedom of movement constitutes the essence of the integration project - as well as a fundamental right of individuals. ${ }^{22}$

Measures to prevent or limit cross-country mobility have been introduced both at the EU and the national scale - not without tensions. It was reported that as early as the end of March 2020, the majority of EU Member States had suspended the terms of the Schengen Agreement and reintroduced some form of border control. ${ }^{23}$ Safeguarding of public health is among the grounds on which national measures limiting freedom of movement can be adopted. ${ }^{24}$ However, the Member States' initial reactions varied and only converged at a later stage. It has been noted that such convergence was mainly due to 'regulatory emulation' - the reciprocal influence in regulatory endeavours aiming at limiting the spread of the infection. ${ }^{25}$

At EU level, after an initial call of caution to Member States in reintroducing border controls and demand for coordinated measures as regards mobility, the EU institutions changed approach. ${ }^{26}$ On 16 March, the Commission adopted two different documents addressing issues related to cross-country mobility and freedom of movement in a time of pandemic: one titled 'COVID-19 Guidelines for border management measures to protect health and ensure the availability of goods and essential services ${ }^{27}$ and the other, a Communication, titled 'COVID-19: Temporary restriction on non-essential travel to the EU'. ${ }^{28}$ While the latter mainly addresses border closures and travel restrictions from

22 Patrícia Jeronimo, 'COVID-19-Related Travel Restrictions and Mobility Rights: A Test for International Human Rights Standards and EU Citizenship' (2020) 6(2) UNIO-EU Law Journal 9.

${ }^{23}$ Sergio Carrera and Ngo Chun Luk, 'Love thy Neighbour? Coronavirus Politics and Their Impact on EU Freedoms and Rule of Law in the Schengen Area' (2020) CEPS Paper in Liberty and Security in Europe, no. 2020-04, 9.

24 See for instance the treaty provisions concerning free movement for workers (Article 45(3) TFEU) or freedom of establishment (Article 52 TFEU) as well as Article 1 of Directive 2004/38/EC on the right of citizens of the Union and their family members to move and reside freely within the territory of the Member States [2004] OJ L158/77.

25 Alberto Alemmano, 'The European Response to COVID-19: From Regulatory Emulation to Regulatory Coordination? (2020) 11(2) European Journal of Risk Regulation 307.

26 Ibid, 13.

27 European Commission, 'COVID-19: Guidelines for border management measures to protect health and ensure the availability of goods and essential services' $\operatorname{COM}(2020) 1753$ final.

28 European Commission, 'Communication from the Commission to the European Parliament, the European Council and the Council, "COVID-19: Temporary Restriction on Non-Essential Travel to the EU"' COM(2020) 115 final. 
third countries to the EU+ area, ${ }^{29}$ the former is centred on the question of travel restrictions across Member States. ${ }^{30}$ In the opening of the document, the Commission recalls that 'implementation of the Union's policies on checks of persons and goods should be governed by the principle of solidarity between the Member States'. ${ }^{31}$ From that premise, the Commission moves on to acknowledge the possibility for Member States to limit travel into their territories as long as 'the continuity of economic activity' is ensured through, for example, 'the operation of supply chains,, ${ }^{32}$ by allowing transport workers as well as other categories of frontier workers to cross borders for the supply of food and other essential goods. ${ }^{33}$

The situation of 'mobile workers' was addressed in detail by a Commission Communication issued on 30 March outlining 'Guidelines concerning the exercise of the free movement of workers during COVID-19 outbreak' ${ }^{34}$ Here the Commission calls for coordinated action, by reminding Member States that measures limiting cross-country mobility within the EU 'must be necessary, proportionate and based on objective and non-discriminatory criteria'. The guidelines also emphasise the essential nature of work performed by frontier workers, posted workers and seasonal workers. ${ }^{35}$ A special section is dedicated to seasonal workers employed in agriculture - a controversial aspect in many Member States, where the need to ensure the harvesting season led to the adoption of temporary measures favouring seasonal migration yet disregarding health risks for workers in the fields. ${ }^{36}$

29 The 'EU+ area' includes 30 countries: 26 out of the 27 EU Member States as well as the four Schengen Associated States: Iceland, Liechtenstein, Norway and Switzerland.

30 However, these guidelines too address the issue of external borders of the EU (see section $\mathrm{V}$ of the document).

31 European Commission (n 27), 1.

32 Ibid.

33 Ibid.

34 European Commission, 'Communication from the Commission Guidelines concerning the exercise of the free movement of workers during COVID-19 outbreak' [2020] OJC102I/12.

35 The list of those occupations considered to be essential in the context of the pandemic is wide and long, covering health professionals, fishermen, workers in the pharmaceutical and medical devices industry, persons working on "critical or otherwise essential infrastructures', IT and communication professionals and workers 'involved in the supply of goods'. With specific regard to the mobility of health professionals, see Giacomo Di Federico, 'COVID-19 and Labour Law: Free Movement of Healthcare Personnel within the EU' (2020) 13(1S) Italian Labour Law e-Journal.

36 Vincenzo Pietrogiovanni, 'Labour without the Law: Migrant Food Workers in Italy' (2020) 15 Futures of Work, https://futuresofwork.co.uk/2020/07/13/labour -without-law-migrant-food-workers-in-italy/, accessed 18 June 2021; Vladimir 
Overall, EU measures on limitations and exceptions to cross-country mobility of EU citizens illustrate how the tensions between a social and an economic dimension - as well as between the national and the supranational regulatory dimensions - of EU integration are constant and consistent also in time of emergency. The exemptions granted to those categories of workers whose work is deemed essential to the functioning of the internal market, but whose health is not equally safeguarded, ${ }^{37}$ show a lack of 'vertical' solidarity between the EU and its citizens and little attention to the social aspects of the internal market. In the pandemic emergency, citizenship status and worker status ensure a different exercise of mobility rights. Also, the establishment of a European labour market grounded on free movement is undermined. These aspects reflect multiple asymmetries in the construction of a Social Europe and call for a more consistent approach to solidarity as a principle guiding the functioning of the EU economy, especially in times of emergency.

\subsection{Reception of Refugees and the COVID-19 Pandemic: A Crisis within a Crisis}

As illustrated in Bengoetxea's chapter in this volume, since 2015 there has been a clear tendency for EU countries to address the challenges posed by increased refugee movement to Europe through ad hoc 'crisis' measures. Arguably, these measures have deviated from well-established human rights norms, legitimising contested European practices such as externalisation of migration control, prolonged detention and destitution, and non-admission at the border. ${ }^{38}$ These measures have not only impacted on third country nationals' rights but have also interfered with the right to free movement of EU nationals, disrupting the Schengen acquis to the point of total collapse. ${ }^{39}$

Bogoeski, 'Harvesting Injustice' (Verfassungsblog, 21 April 2021) https:// verfassungsblog.de/harvesting-injustice/, accessed 18 June 2021.

37 Zane Rasnača, 'Essential but Unprotected: Highly Mobile Workers in the EU during the Covid-19 Pandemic' (2020) ETUI policy brief no. 9/2020.

38 See among others Cathryn Costello, 'Overcoming Refugee Containment and Crisis' (2020) 21(1) German Law Journal 17.

39 Measures reintroducing border controls have been employed by Member States since 2015 onwards, oftentimes going beyond what is strictly permissible pursuant to the Schengen Borders Code. A combination of security grounds due to terrorism and mass migration through the EU external borders has been used as a justification to retain and extend such measures, recently replaced by public health considerations due to the pandemic. A list of Member States that have reintroduced border controls is available at https://ec.europa.eu/home-affairs/sites/homeaffairs/files/what -we-do/policies/borders-and-visas/schengen/reintroduction-border-control/docs/ms _notifications_-_reintroduction_of_border_control_en.pdf. 
The pandemic has, in fact, struck at a time of general erosion of rule of law in Europe. It has exposed the competing interests underlying migration policy in the EU, namely protection of migrant rights versus national security and social cohesion, making the boundaries of inclusion and exclusion more salient and recourse to constitutional values vital. ${ }^{40}$ A concrete example of this is the domino effect of restrictive arrangements implemented by countries located at the EU external borders. Such arrangements include suspension of the right to apply for international protection as a provisional measure dictated by public health considerations, as well as further restriction of movement both between Member States and within Member States (as in the case of, for example, the Greek islands). ${ }^{41}$

Although, in view of the pandemic, responsibility sharing has materialized on a voluntary basis in relation to certain groups of refugees, such as unaccompanied minors, ${ }^{42}$ the Dublin Regulation, ${ }^{43}$ which has proved likely to result in human rights violations in the context of mass refugee movements, ${ }^{44}$ continues to apply despite health risks. ${ }^{45}$ In the new proposals for a reform to the Common European Asylum System (CEAS) ${ }^{46}$ the Commission does emphasise the need for an embedded solidarity system and seeks to compensate for its compulsory

40 Vladislava Stoyanova, 'Inherent Instability or Tipping of the Balance: Populism, Immigration and Liberal Democracies' in Vladislava Stoyanova and Stijn Smet (eds), Migrants' Rights, Populism and Legal Resilience in Europe (CUP 2021).

${ }_{41}$ See e.g. Eleni Karageorgiou, 'The Impact of the New EU Pact on Europe's External Borders: The Case of Greece' in Sergio Carrera and Andrew Geddes (eds), The EU Pact on Migration and Asylum in Light of the United Nations Global Compact on Refugees: International Experiences on Containment and Mobility and Their Impacts on Trust and Rights (EUI 2021).

42 See Evangelia (Lilian) Tsourdi, 'COVID-19, Asylum in the EU, and the Great Expectations of Solidarity’ (2020) 32(2) International Journal of Refugee Law 374.

43 Regulation (EU) No 604/2013 of the European Parliament and of the Council of 26 June 2013 establishing the criteria and mechanisms for determining the Member State responsible for examining an application for international protection lodged in one of the Member States by a third-country national or a stateless person (recast) [2013] OJ L180/31.

44 See e.g. Opinion of AG Sharpston in Case C-646/16 Jafari v Bundesamt für Fremdenwesen und Asyl, ECLI:EU:C:2017:443 and Case C-410/16 A.S. v Republika Slovenija, where she contends that the Dublin Regulation has not been designed to tackle mass refugee movements and that the application of the so-called first entry criterion stipulated in Article 13(1) may lead to unfair responsibility allocation, contrary to Article 80 TFEU.

45 See European Council on Refugees and Exiles (ECRE), AIDA Report August 2020, 'The implementation of the Dublin III Regulation in 2019 and during COVID-19', pp.34-5.

46 European Commission, 'Communication from the Commission to the European Parliament, the Council, the European Economic and Social Committee and the 
character by widening the ways in which Member States can contribute to solidarity measures, through, for example, capacity building in third countries and return sponsorship. ${ }^{47}$ It is, however, doubtful that such proposals will ensure enhanced protection of refugee rights and a fair distribution of responsibilities in the field when the default link between external borders management and responsibility is retained and Member States are allowed to circumvent their asylum obligations by contributing to interstate solidarity through migration management measures.

Within this context, the COVID-19 emergency measures appear to have provided the basis for greater consolidation of executive power, under the pretext that the 'crisis' justifies it. In this sense, a continuation of the techniques that have been prevalent during the 2015 migration 'crisis' is evident. The argument to be made here is that exceptional, crisis-led measures adopted in different contexts (migration control and the pandemic, among others) reinforce each other and there is a risk of further consolidation of 'emergency-like' situations creating an environment of uncertainty. To avoid a normalisation of emergency, the new proposals combined with existing law and policy arrangements need to be persistently evaluated under the light of the EU constitutional principles, and in particular the principles of legality and solidarity. On the other hand, positive developments that occurred at the national level due to the pandemic (such as regularisation of the status of migrants in Portugal and relocation of unaccompanied migrants from Greece) should not be underestimated. The question that arises is to what extent the future reform of European asylum law does reconcile pragmatism with a more principled approach, institutionalising the positive developments in the aftermath of the pandemic.

\section{CONCLUSIONS}

Despite the principle of solidarity's constitutional weight within the EU legal order, the contributions to this volume illustrate the limits of its implementation in the field of social rights, labour relations, and mobility. The arrangements described and discussed speak less about solidarity as distributive justice or social fairness and more about national responsibility, conditionality, economic concern and enlightened self-interest. In light of this, solidarity

Committee of the Regions on a New Pact on Migration and Asylum' COM/2020/609 final.

47 European Commission, Proposal for a Regulation of the European Parliament and of the Council on asylum and migration management and amending Council Directive (EC) 2003/109 and the proposed Regulation (EU) XXX/XXX [Asylum and Migration Fund] COM/2020/610 final, 11. See also Proposal Part IV Solidarity, Articles 45-60. 
seems to move away from its constitutional imperative as a founding value of EU law and policy, towards a neoliberal thinking of dignity and rights through the prism of the internal market. From this shift follows the need to reconcile the social with the economic and the political in the EU, as well as to reconnect a collective dimension of democratic participation and solidarity with the individual dimension of rights. The need to restore a principled approach to solidarity has become even more urgent in the aftermath of the COVID-19 outbreak. What this volume suggests is that for European solidarity to work beyond emergencies, as a value embedded in the system, there is a need for deep legal and social reforms addressing the limits and tensions in the broad functioning of Social Europe. Such reforms would, however, require enhanced cooperation and the participation and commitment of the different actors involved in the project of EU integration, namely Member States, affected parties, EU agencies and courts, as well as citizens and migrants alike.

Ultimately, the discussions put forward in the volume will hopefully generate a debate on reassessing and readdressing the challenges for Social Europe that are currently limiting economic and social development for the Union itself, for its Member States and citizens, and for whoever is (even temporarily and in marginalised contexts) under their jurisdiction. The pandemic has exacerbated social, economic and political inequalities and increased the need to demanding that equality and equal opportunities are effectively put in place, beyond a contingent approach based on emergency remedies. In light of this and on the basis of the limits and tensions that this volume addresses, our ambition and aspiration is that socio-legal research on the principle of solidarity in the EU will move forward, towards the understanding of those practices undertaken at the 'grassroots' levels and from below, so as to connect them with, and eventually inform, the EU constitutional framework. 